\title{
The Relevance of Own-Source Revenue to the Independence of West Sulawesi
}

\author{
Muhlis Madani \\ Universitas Muhammadiyah Makassar \\ Makassar, Indonesia \\ Muhlis.madani@unismuh.ac.id
}

\begin{abstract}
This study aims to outline the relevance of westsulawesi's OSR with local independence as the carrying capacity in accelerating the development execution in West-Sulawesi. The approach used is mix between fiscal decentralization approaches, degree of fiscal needs and fiscal capacity. It'll conclude a more comprehensive and representative, data used is secondary data derived from Regional Budget Fiscal in 2013/2014, survey of literature and studies done previously to strengthen study analysis. It showed the independence of West Sulawesi province still very low, seen from fiscal degree decentralization in 2014 only $11.15 \%$ in the proportion of OSR aspect to regional revenue and BHPBP against Total Revenue Region approximately $4.44 \%$, while the degree of fiscal needs in 2014 at OSR proportion to the regional income approximately $11.15 \%$. OSR + BHPBP proportion of total public expenditures approximately $15.04 \%$, and the OSR proportion to indirect expenditures approximately $54.36 \%$. and fiscal capacity index is 0.4759 (low).
\end{abstract}

Keyword: Decentralization, Own-Source Revenue (OSR) and Local Government

\section{INTRODUCTION}

2001 is the most historic moment in the context of regional autonomy in Indonesia, because in that year deregulation use of authority that formerly rested on centralistic governance turned into decentralized. In this condition, it become a tidbit for the community leaders who are in the western part of South Sulawesi to build its own province which is then known as West Sulawesi province via Law No. 26 of 2004 on the Establishment of West Sulawesi province with the aim to further the welfare of society and streamline the public service. These objectives can only be achieved if it has a strong financial carrying capacity especially those stemming from OSR and professional human resources.

The concept of decentralization and the creation of an efficient public service as the goal of the establishment of West Sulawesi in accordance with TAP MPR No. IV / MPR / 2000 that the decentralization policy areas to achieve improved public services and the development of creativity of local government, conformity relationship between the center and regions and between the region itself within the authority and finances to ensure a sense of nationalism, democracy, prosperity and the creation of a wider space for local independence. Thus, the mandate of MPR, of course, must be actualized in a tangible form through clean government management and morality within the Government of West
Sulawesi in order to create local independence and prosperity achieved.

Since regional autonomy had been launched in 2001 to present the financial inequality between the center and regions as between regions, the area is still very visible, especially in the province which was divided after the reform like Gorontalo, West Sulawesi, West Papua, and North Maluku. Comparison between the OSR with a budget sourced from the center ranges from 30\%: $70 \%$ with variations contributions OSR, 208 regencies / cities have OSR contribution less than $20 \%$, as many as 65 districts / cities have contributed 20.1 OSR \% $-40 \%$, as many as 17 districts / cities that have the OSR ability more than $50 \%$ from the total receipts of its APBD (state budget) [1].

West Sulawesi is rich in natural resources but still have poor people around 190,000 inhabitants and apparatus resources that still require increasing competence. Therefore, the Government of West Sulawesi must perform acceleration in the improvement of human resources, especially in the regional financial management.

OSR owned by the Government are set out in regulation (Act) No. 28 of 2009 on Local Taxes and Levies. The birth of the OSR legal basis shows that the government wanted the role of OSR in supporting the creation of financing the budget of the region itself.

Out of 33 provinces in Indonesia, about 14 provinces reaching local government revenue contribution to $40 \%$ $50 \%$, only one province that came from Eastern Indonesia namely South Sulawesi and as many as 17 provinces OSR contributed approximately $10 \%-30 \%$ are all derived from Eastern Indonesia, even the most tragic because there are still governments that have contributed revenue of less than $10 \%$, namely Nanggroe Aceh Darussalam, Papua, and West Papua. In line with observation result [2] distinguishes between contributions OSR province with the contribution of OSR districts / cities with a review of regional autonomy implemented since January 1, 2001. OSR to provincial and district / city is relatively small compared to the total budget. For the provincial average of only $25-30 \%$, while for the district / city is only about $15-20 \%$ of the total budget. Most still be obtained from the DAU. That means, the dependence on the central area remains high.

Confirms that argument by showing the data that for five consecutive years in mind that (1) a comparison between OSR with a budget that comes from the central government range 
from 30\%: $70 \%$, and (2) the existence of a wide variety of donations OSR from various districts / cities in Indonesia, namely: 208 districts / cities contributing OSR less than 20\%, 65 districts / cities accounted for $20.1 \%-40 \%$, and only 17 districts / cities that have the ability to contribute revenue of over $50 \%$ of total revenue budget [1].

That regional financial performance can be determined by using the degree of independence of the region to measure how much revenue from the region can finance the needs of the region, the formula used is the proportion of revenue to total spending areas, the proportion of OSR on routine expenditures, OSR proportion of added Tax Revenue and Non-Tax to Total Expenditure Regions [3]. According to [4] to measure the financial performance of the government, then developed a standard expenditure analysis, benchmarks of performance and cost standards.

\section{RESEARCH METHODOLOGY}

To answer the problem, the analysis of this research used exploratory methods. The method is very flexible and not structured so as to facilitate the search for ideas and guidance on problem situations. The approach used in assessing the independence of West Sulawesi province is a mix between fiscal decentralization approach, the degree of fiscal needs and fiscal capacity. Through three approaches to the conclusion that it would be more koprehensif and refresentatif. while the data used in this research is secondary data derived from the Regional Budget for Fiscal Year 2013 and 2014, and the research literature survey ever done before to strengthen the research analysis study.

\section{RESULTS AND DISCUSSION}

OSR is a pure source of revenue from the area, which is the main capital for the region as the cost of governance and local development. Although OSR is not entirely able to finance the total expenditure of the area, but the proportion of the total revenue OSR area remains an indication of a degree of financial independence of local governments. If seen from the amount OSR as a parameter, the independence of West Sulawesi very far behind because its OSR is very low and even lower than OSR of Makassar City for the fiscal year 2014 amount 160.432 billion, can be seen in the last two years of data as it existed in the table 01 .

The data in table 01 shows that among the three sources of revenue Sulbar the most is local taxes than other sources. The quantity of local revenue is still very low even further behind its mother province namely South Sulawesi with local revenue for the fiscal year 2014 a number of 1,301,646 trillion, so it is not free to formulate its budget in financing development projects. To measure how large the area of financial inability of West Sulawesi in supporting the budget revenue and expenditure, the authors use an independent variable with fiscal decentralization approach.

\section{A. Fiscal Decentralization}

Fiscal decentralization is an approach used to determine the independence of the fiscal arrangements areas where local governments can freely allocate the budget even though the funds came from the center unless the Special Allocation Fund (DAK). To measure the degree of fiscal decentralization West Sulawesi Provincial Government can be determined by calculating the local revenue contribution to the regional revenue and contributions BHPBP of Total Revenue Regions. For more details, the author describes below:

Under Article 1 Paragraph 15 of Law No. 17 of the State Finance / Regional, local revenue is the right of all local authorities recognized as an addition to net asset value. Revenue intended there are three groups of OSR, the Balancing Fund and Other legitimate income. This article only highlights local revenue as part of local revenue sources of revenues coming from the region concerned. Therefore, West Sulawesi province as an autonomous region should have a role local revenue that is more dominant than the equalization fund, but the reality shows that the funds derived from the center is still very high so it does not yet appear independence and ability to manage its own family through income sources that are owned.

Despite the presence of West Sulawesi province in the category youngest formation after the reform, the role of government expected to bring West Sulawesi as independent province. If seen from the parameter independence with reference to the degree of fiscal decentralization, the one among these parameters is to measure the proportion of local revenue to total local revenues. See in the table 03 .

The table 03 shows the contribution of OSR in West Sulawesi province to the total regional revenues in 2013 approximately $08.49 \%$ and approximately $11.15 \%$ in 2014 . This value shows that over the past two years, government revenue of West Sulawesi province is dominated by revenues from the central government about $91.51 \%$ in 2013 and by 2014 approximately 88.85\%, thus the journey toward independence of West Sulawesi province will still be experienced a long process. Similarly, when viewed from the height contribution of OSR against regional revenues over the last two years only about $2.66 \%$. The contribution changing is much less significant compared with other provinces relatively the same age with the province of West Sulawesi such as Bangka Belitung with OSR contribution to the total regional income of about $25.48 \%$, $64.50 \%$ Banten, Gorontalo Province $14.40 \%$

To make an independent of West Sulawesi Province then it needs to be emphasized in the effort as outlined by the World Bank (2003), namely; a) on good governance will encourage high-quality financial management and a stronger fiscal position will improve city services and create a cycle of development continues to move forward [5].

For sharing and Non-sharingTax (BHPBP), which comes from the central government to the local government distribution varies greatly because the great BHPBP received by local governments rely heavily on the amount of potential tax and natural resources owned by the regions concerned. Based on data from Indonesia Tanah Airku (2007) that the wealth of the West Sulawesi consists of coal with potential of 
322142102 tons, 88819 tons of iron ore contained in Polewali Mandar, copper potential 50,000 tons, 15,000 tons Zeng and manganese, limestone at 3,864.430 tons in Majene, marble potential with a potential of 570937 tons and the potential of oil and gas there in District Bloka Surumanal Pasangkayu, Kurna, BudangBudong, and Karama, staffed proportionally.

The table 04 shows that the contribution BHPBP to the expenditures in 2013 only 02.91 and in 2014 contributions BHPBP only $04.44 \%$. It appears that West Sulawesi province has not optimally managed the tax potential and natural resources that is owned, so reception from central BHPBP still very low. Comparing with other provinces after reformation and its formation is relatively the same age as the West Sulawesi province such as North Maluku has BHPBP contribution to total regional expenditures about $12.43 \%$, about $12.57 \%$ of Banten province, Bangka Belitung around 10.57 and around Gorontalo Province $03.34 \%$.

\section{B. Contribution OSR to Regional Expenditures.}

Pursuant to Article 16 paragraph (4) of Law No. 17 of the Financial State / Local that regional expenditures are all local government liabilities recognized as reduction in net worth. The Heaviness of region expenditures dependent on the amount of OSR owned by the respective regions coupled with balance funds from central government. The existence of West Sulawesi province as an autonomous region certainly is expected has OSR which is be major contributors in supporting region expenditures. The expectation is highly correlated with the ability of local governments in exploring sources of revenue in order to truly stand on its own feet.

Own-Source Revenue which is still very low, leading to high dependence on central government [6]. What happened in West Sulawesi has been studied by Mardiasmo in that the portion of OSR is still relatively small, the national average of OSR only contributes $12-15 \%$ of total local revenues, while $70 \%$ still depend donations and assistance from the central government [7].

Based on data from the percentage distribution of the reception area to entire the district of Indonesia from 19911995 showed that average contribution of OSR is still far lower (12.63\%) compared with the donations and support by the central government $(70.52 \%)$.

The table 05 shows that contribution of OSR in the West Sulawesi against local government expenditures is still very low at $08.52 \%$ in 2013 and $10.60 \%$ in 2014 while local government expenditures continues to increase along with the dynamics of the budget. Financial year 2014 local government of West Sulawesi province has swelling budget of Rp 56161 Billion if compared to local government expenditures budget year 2013. In fact, the number of the expenditure more than OSR in 2013. Therefore, the Government of west sulawesi should have the more concrete efforts to boost OSR by optimizing the expansion and intensification of OSR sources including pioneering the establishment of Local Owned Enterprises (BUMD) which is expected to become the locomotive of the regional economy as well as being a contributor to the acceptance of OSR in West Sulawesi.

\section{Proportion of OSR + BHPBP/Regional Total Expenditures}

For Sharing and Non-SharingTax (BHPBP) is also commonly termed Revenue Sharing Fund (DBH). These funds come from the State Budget (APBN) shared out to the area at certain percentage with regard to potential producing region. The amount of the provision of DBH from the center to the regions heavily dependent on potential of the area and the results obtained either in form of taxes or the result of natural resources are managed so far.

West Sulawesi region's autonomy can also be seen from the quantity of OSR and BHPBP correlated with the regional expenditures. It is important to be studied considering the OSR and BHPBP are both local revenue expected to have a positive contribution to local expenditure as sources of funding to carry out acceleration of development in West Sulawesi. Without adequate income support area, will certainly slow down the development process and lead to less than optimal public services.

The table 06 shows that the contribution of OSR and BHPBP to the local expenditures only $11.59 \%$ in 2013 and 15.04 in 2014. Apparently, those both are less significant in supporting the regional expenditure in West Sulawesi. Even when viewed from the angle of the increase in contributions over the last two years only about $3.45 \%$. This shows that the Government of West Sulawesi province is still very low financial performance in managing financial resources used as the local revenue, while on the other side of the Government of West Sulawesi much needed sources of financing to fund the infrastructure and the public services, so that communities are touched by development which is in the end they can enjoy the results of development which are recommended by the government for this.

To boost its independence, the various natural potential contained in the bowels of the earth of West Sulawesi should be managed in partnership with other investors that provide proportional benefits to regional income. If the potential wealth is managed by the government along with the domestic or foreign investors, beside increase the OSR will also increase DBH Government of West Sulawesi province.

\section{Proportional of OSR to Indirect Expenditures}

Based on Minister of the Interior No. 30 of 2007 on Guidelines for Preparation of State Budget that indirect expenditures are budgeted expenditure not directly related to the implementation of programs and activities. Expenditure in this category is the personnel expenditure, expenditures interest, subsidies, grant expenditures, social assistance expenditures, profit sharing expenditures, financial aid expenditures, unexpected expenditures, additional income for Civil Servants (PNS), allowances to legislators, salary and benefits and operational support costs for regional head and deputy head of area as well as expenditures of land and building tax collection.

If indirect expenditures are linked to budgeting of Provincial Government of west sulawesi then the budget issued relating to the financing on a regular basis should be prepared to fund a variety of local needs. In this condition. OSR as a source of local revenue should be able to become the carrying capacity of OSR even in quantity OSR should has higher value than the revenue that comes from the center so identity is visible of West Sulawesi province as an autonomous region. To discover this, can be seen in the table 07 .

The table 07 shows that OSR of West Sulawesi province has not able to finance the expenditures that are routine and can 
only fund of about $33.27 \%$ in 2013 and approximately $54 \%$ of the total funding needs routine to be prepared by local government in each year. Government of West Sulawesi province is still in need of funds from the center about $46 \%$ annually to fund a variety of routine activities of local government, including salaries of civil servants. Very risky, if the existence of West Sulawesi province seen in perspective as an autonomous region because ideally a provincial dependence on central government grants should be minimized and the OSR should become greatest financial resources. This condition is precisely reversed, because budget issued that are routine just is not able to be funded by the Province of West Sulawesi moreover programs and activities that are an investment.

\section{CONCLUSION}

After reviewing and analyzing the various descriptions above, Picture of Own-Source Revenue (OSR) and its Relevance to the independence of the province of West Sulawesi is still very low, can be seen in aspects of fiscal decentralization and fiscal needs among others, the degree of fiscal decentralization in 2014 only reached $11.15 \%$ on aspects of the proportion of OSR to the regional income and BHPBP of Total regional revenue around $4.44 \%$. The degree of fiscal needs in 2014 in the proportion of OSR to the regional income of about $11.15 \%$, the proportion of OSR + BHPBP to total regional expenditures approximately $15.04 \%$, and the proportion of OSR against indirect expenditures approximately $54.36 \%$. and fiscal capacity index is only 0.4759 (low category).

\section{ACKNOWLEDGMENT}

We would like to thank the University of Muhammadiyah Makassar specially to the Faculty of Social Science and Politics and Faculty of Teacher Training and Educatian. We send our best appreciation to all informants involved for giving more information regarding to the research for the complement of the research.

\section{REFERENCES}

[1] Hamid, Edy Suandi, dan Malian, Sobirin, 2005. "Memperkokoh Otonomi Daerah", UII Press, Yogyakarta

[2] Sarundajang, "Birokrasi Dalam Otonomi Daerah Upaya Mengatasi Kegagalannya”, Pustaka Sinar Harapan : Jakarta, 2003.

[3] Hali, M.S., Saranani, Fajar., Baheri. "Potensi Pajak Dan Retribusi Daerah Kota Kendari. Jurnal Progres Ekonomi Pembangunan", Vol. 1, No. 1, 2016.

[4] Sari, Eka Nurmala. "Konsep Anggaran Dalam Perspektif Balance Scorecard: Suatu Tinjauan Teoritis. Jurnal Riset Akuntansi Dan Bisnis, Vol. 10 No. 2, 2010.

[5] Ratna, Ikhwani. "Analisis Kinerja Keuangan Daerah dan Strategi Pembangunan Kota di Era Otonomi Daerah Pada Kota Pekanbaru", Jurnal El-Riyasah, Vol. 3, No 1, 2012.

[6] Lede, J.W. "Pengaruh Dana Alokasi Umum, Dana Alokasi Khusus Dan Dana Bagi Hasil Terhadap Peningkatan Pendapatan Asli Daerah Melalui Belanja Modal Sebagai Variabel Intervening". Jurnal Ilmu \& Riset Akuntansi Vol. 1 No. 12, 2012.

[7] Lestariningsih. "Pengelolaan Penerimaan Daerah Melalui Desentralisasi Fiskal Dalam Penyelenggaraan Otonomi Daerah". Jurnal Spirit Publik Vol. 9, Nomor 1, 2014. 